\title{
The impact of the Krakatoa eruption in 1883 on the population of Rhinoceros sondaicus in Ujung Kulon, with details of rhino observations from 1857 to 1949
}

\author{
Nico J. van Strien ${ }^{1} \&$ Kees Rookmaaker ${ }^{2}$ \\ ${ }^{1}$ Nico J. van Strien died in 2008. \\ ${ }^{2}$ Rhino Resource Center, 4 The Grange, Lower Caldecote SG18 9ET, United Kingdom \\ Email: ${ }^{2}$ rhino@ rookmaaker.freeserve.co.uk (corresponding author)
}

Date of publication (online): 26 January 2010 Date of publication (print): 26 January 2010 ISSN 0974-7907 (online) | 0974-7893 (print)

Editor: Susie Ellis

\section{Manuscript details:}

Ms \# 02267

Received 27 July 2009

Final received 08 December 2009

Finally accepted 12 December 2009

Citation: Strien, N.J. van. \& K. Rookmaaker (2010). The impact of the Krakatoa eruption in 1883 on the population of Rhinoceros sondaicus in Ujung Kulon, with details of rhino observations from 1857 to 1949. Journal of Threatened Taxa 2(1): 633-638.

Copyright: (๑) Nico J. van Strien \& Kees Rookmaaker 2010. Creative Commons Attribution 3.0 Unported License. JoTT allows unrestricted use of this article in any medium for non-profit purposes, reproduction and distribution by providing adequate credit to the authors and the source of publication.

Author Details: Nico van Strien details are at the end of the article. Kees Rookmaaker is a Senior Research Fellow in the Department of Biology at the National University of Singapore, working on providing the works of Charles Darwin and Alfred Russel Wallace Online. He is a member of the IUCN Asian Rhino Specialist Group and the Chief Editor of the Rhino Resource Center.

Author Contribution: This paper was initiated before Nico VAN STRIEN's death and he made many suggestions at the time about the best way to investigate this interesting period of nature conservation in the Dutch East Indies. KeEs ROOKMAAKER wrote the paper.

Acknowledgements: KR thanks the family of the late Nico van Strien for their support and permission to publish this paper. Nico left behind his wife Tineke as well as two sons, Maarten and Willem. Much of the literature cited in this paper can be found, often in a full-text version, on the website of the Rhino Resource Center (www.rhinoresourcecenter.com), which aims to assist research and conservation of the rhinoceros worldwide by collecting all publications and maintaining archives. The work of the Rhino Resource Center is sponsored by SOS Rhino and the International Rhino Foundation.
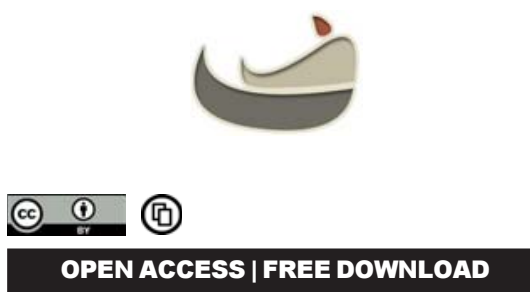

Abstract: A recent suggestion that the entire population of the Javan Rhinoceros in Ujung Kulon National Park was annihilated by the effects of the eruption of the Krakatoa in 1883 is investigated. Based on a review of contemporary reports, it is shown that people survived the waves and remained settled in one village until 1906 when it was evacuated during a plague of tigers. The first report of a rhinoceros in the peninsula of Ujung Kulon dates from 1857 and the animals were occasionally reported from the area afterwards. There is no indication from the available estimates and sightings that rhinos were exterminated in the area. Ujung Kulon has been a protected area since 1921. Rhino numbers ranged upwards to about 40 or 50 for most of the period until 1949. The population of Rhinoceros sondaicus is not a new founder population established after the eruption of the Krakatoa in 1883.

Keywords: Conservation, founder population, Java, Javan Rhinoceros, Krakatoa, Ujung Kulon.

\section{INTRODUCTION}

The Javan Rhinoceros (Rhinoceros sondaicus Desmarest, 1822) (Mammalia: Rhinocerotidae) is one of the rarest mammal species on earth, which survives only in the Ujung Kulon National Park on the western tip of Java and in the Cat Tien National Park in the southern part of Vietnam. Fernando et al. (2006) recently studied the genetic diversity of the Javan Rhinoceros by analysing the DNA obtained from dung samples of both these widely separated populations. In line with previous taxonomic findings by Groves \& Guérin (1980), it was found that the two populations represent separate evolutionary significant units which shared a common ancestor from around 2 million years ago to 300,000 years ago. As part of their investigations, they suggested that the catastrophic explosion of Krakatoa in 1883 not only annihilated the human settlements in Ujung Kulon, but also wiped out the rhinos from the peninsula (Fernando et al. 2006: 445). In their opinion, the remaining rhinos in Ujung Kulon are likely to be the progeny of animals which invaded the area after 1883 from other parts of southern Java.

We investigate the historical evidence of this scenario proposed by Fernando et al. (2006). There are only limited data regarding the rhino population in western Java, but we will place the existing estimates in the perspective of the conservation and management of Ujung Kulon from the first reports of rhinos in the area from around 1850 to 1949. We will also look at the information on human settlements on the peninsula around the time of the eruption of the Krakatoa, to assess how they were affected by this event. The wide time period is chosen to gain insight in the possible changes in the rhino population, as well as to document a significant period in the history of nature conservation in Indonesia and on the island of Java in particular.

Fernando et al. (2006: 447) quite rightly state that conservation and management of the two last remaining populations of Rhinoceros sondaicus require "an understanding of its demography, ecology, behaviour, genetics, and their interactions." This species of rhinoceros has always been rare, or, possibly more accurately, sightings have always been uncommon throughout its large former range (Groves 1967). In comparison to the other species of rhinoceros, the biology of the Javan rhinoceros has been quite exceptionally well studied and documented, mainly through the efforts of three pioneers in nature conservation.

A comprehensive review of all knowledge about the Javan Rhinoceros was published in Dutch in 1941 by Henri Jacob Victor Sody (1892-1959). Sody studied the systematics and biogeography of Asian mammals during a period of 30 years (19181947) spent on Java teaching at the secondary agricultural school in Bogor (Becking 1989). As a result of the Japanese occupation of Indonesia at the time, very few copies of this book remain, probably no more than ten in total. It was important enough to be translated into German and this version is widely available (Sody 1959). 
Ujung Kulon has for many years been a priority for nature studies by Andries Hoogerwerf (1906-1977), who from 1931 to 1937 worked in the Botanical Garden in Buitenzorg (Bogor) as Head of the Department for Hunting and Nature Conservation, and from 1937 onwards he was in charge of nature conservation in the Dutch East Indies. Hoogerwerf made numerous visits to Ujung Kulon during the 1930s and 1940s. His observations were described in many smaller articles highlighting the plight of the fauna of the reserve, as well as in his magnum opus, 'Udjung Kulon, the land of the last Javan rhinoceros', which will long remain critical to all further surveys in the area (Hoogerwerf 1970). Further studies on the ecology and behaviour of the Javan rhinoceros in Ujung Kulon were undertaken by the Swiss biologists Rudolf Schenkel (19142003) and his wife Lotte Schenkel-Hulliger (Schenkel \& Schenkel 1969; Schenkel 1971).

\section{Ujung Kulon before 1883}

On 19 January 1752, the Swedish chaplain and amateur naturalist Pehr Osbeck (1723-1805), who attended lectures by Linnaeus in Uppsala, anchored in Meeuwenbaai (Mew Bay, West Java) on his return from China. He recorded that it was hazardous to reach the shore due to the abundance of corals. Walking from the beach inland, he found the forest very thick, wet, and dangerous due to the abundance of tigers and other carnivores (Osbeck 1765: 352-353). Apparently, he did not encounter any of these animals, nor does he mention the presence of rhinos. Osbeck was correct to state that the bay was then the usual anchoring place for ships travelling through the region. For instance, Captain James Cook also passed near the shore of Prince's Island (Prinseneiland) on board the Endeavour on 1 October 1770 (Hawkesworth 1783: 301).

The extreme western tip of Java remained unexplored until the start of the nineteenth century. In 1807, there was an attempt to construct a new naval port on the shore opposite Pulau Peutjang (Meeuweneiland) under orders of the Governor-General Herman Willem Daendels (1762-1818), but the work was abandoned when the men succumbed from breathing noxious vapours (Hoogerwerf 1970: 9). In 1816, Captain Basil Hall (1788-1844) anchored in Mew Bay, and provided the following narrative: "While the boats' crews were busily engaged in filling the water-casks, one or two of the officers endeavoured to penetrate the woods in search of game; but the jungle was found everywhere completely impervious. The whole forest rung with the discordant screams of birds, principally of the parrot tribe, dressed in a plumage as brilliant and beautiful as their notes were unmelodious. In every other respect, the scene was perfectly undisturbed, nor could there be distinguished a single trace of inhabitants, or any symptom to tell that the spot had ever been visited since the creation" (Hall 1826: 6).

Two expeditions organised in 1853 and 1854 by the "Koninklijke Natuurkundige Vereeniging" (Royal Society for Natural History) to explore the coal seams near Muara Tjukuja (Meeuwenbaai) did not lead to any further development. At that time, and for a considerable period afterwards, there was only one settlement in the region, a kampong (village) called Djungkulan or Djungkulon near this bay (Maier 1853; Smit 1854). It is likely that visitors to the area rarely penetrated inland from the coast into the tiger-infested forests which have been characteristic for this peninsula (Hoogerwerf 1970: 11).

The rhinoceros was not reported in the area until Arthur Adams (1820-1878), naval surgeon and conchologist, gave an account of his visit to Mew Bay (Meeuwenbaai) in his voyage on board the Actaeon in 1857. He mentioned a little waterfall, which then existed about 2 miles east of the only village. He stated that "there is a legend among the sailors of a rhinoceros having charged a party watering here some time previously." Although this could have been an unfounded rumour, he also found the ground "literally ploughed up by the tracks of these unwieldy pachyderms" (Adams 1861: 7328).

A lighthouse was first built in 1877 on Java's westernmost point, Tanjung Layar, and replaced by a second structure in 1897. According to Kal (1910), the settlement consisted of the lighthouse, a residence for the supervisor and quarters for the workers. It was about 15 minutes walk from the beach, connected through a sandy road which was 2-3 meters wide and fringed by shady trees and a few coconut trees. There were six wells containing good drinking water. The European graveyard then had three graves. The village of Djungkulan near the lighthouse also had two small satellites called Tjikula and Rumah Tiga in the 1870s. There was relatively little human presence in the whole peninsula.

\section{The effects of the Krakatoa eruption in 1883}

When the Krakatoa erupted on 27 August 1883, huge tidal waves ran across the Sunda Straits towards the coast of Java. According to Verbeek (1885), who gathered the available information on the disaster from local sources, most of the people living in the villages in Ujung Kulon gathered at the lighthouse (about 40m) and survived the eventful days. He suggested that all available information showed that the waves were less than $15 \mathrm{~m}$ high when they reached the Javanese coast and penetrated less than a kilometre from the northern shore. Although the villages and the surrounding lands in Ujung Kulon were inundated, there was relatively little longterm effect on the wildlife.

About 20 years later, Veth (1875: 247) stated that Rumah Tigah in the bay behind Pulau Peutjang was then the only settlement in Ujung Kulon. According to Kal (1910: 139), the village of Djoengkoelon (Djungkulon) opposite Meeuweneiland, with about 40 houses, had been devastated during the eruption, but people had returned there afterwards, only to leave permanently due to a plague of tigers. Similarly, Halewijn (1933) mentioned that the village of some 500 people which existed near the mouth of the Tji Boenar (Tji Bunar) had been abandoned in 1906 due to a plague of tigers. According to Hoogerwerf (1970:11), the whole of Ujung Kulon was evacuated at the beginning of the 20th century, except the small post at the lighthouse. This measure was taken by the government to protect people from the regular outbursts of malaria and dysentery, as well as on account of the number of tigers in the area. Possibly another motive was to facilitate the creation of a new nature reserve.

There is then no evidence that the eruption of the Krakatoa directly influenced the number of people living in Ujung Kulon. Besides the lighthouse, there was only one relatively small village. This was abandoned as late as 1906 due to pressures on the government to provide good living conditions in the province.

The rhinoceros was widely distributed over the island of Java until well into the $20^{\text {th }}$ century and its distribution included the province of Bantam, which borders Ujung Kulon. Rhinos were often shot in the southern part of Bantam in the early part of the century (Sody 1941: 50). Van Weede (1908: 379) hunted rhinos with W. Boreel in 1908 at CikepuH, east of Pelabuhan Ratu on the south coast, stating his regret that the numbers were diminishing. In 1914, a large female rhinoceros was 
shot (after obtaining a special permit) in South-West Bantam by $\mathrm{V}$. de Sturler, who donated the specimen to the Zoological Museum in Buitenzorg (Sturler 1915: 63). It is widely accepted that the last rhinoceros in southern Java was shot at Tasikmalaja by P.F. Franck for the Museum at Buitenzorg on 31 January 1934 (Appelman \& Franck 1934).

Special expedition were always required to observe rhinos in Ujung Kulon. Sijfert Hendrik Koorders (1863-1919) was the first president of the "Nederlandsch Indische Vereeninging voor Natuurbescherming" (Society for Nature Conservation in the Dutch East Indies) founded in 1912. He visited Ujung Kulon from 25 June to 6 August 1892 and mentioned that the peninsula was covered with primary forest and was uninhabited, except for the area around the First Point. He encountered fresh spoor of rhino, besides many deer, tigers and banteng (Koorders 1916). There are three references to the presence of rhinos in Ujung Kulon from the early years of the $20^{\text {th }}$ century. Alfred Ernst (1908: 24$)$ visited the region in 1906 and records that tigers and rhinos were still plentiful. Hugo Bremer went on a hunting expedition near Welcome Bay in 1908, and soon found "eine Menge Spuren der Dickhäuter, die in dem weichen Boden große runde Vertiefungen hinterlassen haben" (Bremer 1908: 59). Kal (1910: 139, cf. Sody 1941: 50) also mentioned that rhinos were present on the peninsula Djoengkoelon.

The killing of rhinos on the island of Java was totally prohibited in an ordinance of 1909 (Staatsblad van Nederlandsch Indië, no. 497, 23 October 1909; Sody 1941: 50). The maximum sentence for this offence was 8 days imprisonment or a fine of 100 guilders. Although poaching continued, rhinos increased along the South coast, and were particularly numerous in Ujung Kulon (Kerkhoven 1926). In 1910 , a local association of big-game hunters called "Venatoria", petitioned the government to acquire exclusive hunting rights in Ujung Kulon, whereby it undertook to follow all regulations strictly and manage the area. The "Nederlandsch Indische Vereeninging voor Natuurbescherming" was not averse to this proposal, because it would give a measure of stability and ensure some form of protection. However, the petition was denied by the government (Hoogerwerf 1970:13).

Eekhout (1911) stated that six permits for mining exploration were granted in February 1910 for both Prinseneiland (Pulau Panaitan) and the peninsula Djoengkoelan. The prospecting was done by the "Maatschappij voor Mijnbouwonderzoek Welkomstbaai" (Company for Mining Exploration in Welkomstbay) founded in Batavia. In August 1910, Eekhout was sent to explore the possibilities, and he reported that, besides at the lighthouse, there were no people resident on the peninsula. The mining appeared unprofitable and the project was abandoned without further intrusions.

In September 1913, a number of leading citizens of Batavia, including the Public Prosecutor, went on a holiday trip to Ujung Kulon, which was said to be the richest in game on the whole island (Hoogerwerf 1970: 12). A banteng was shot, and tracks of rhino were found along the Tjigenter and near the mouth of the Tjitjangkok. The guides estimated that only four or five rhinos were left in the area, because they had been decimated by the Chinese, but one of the guides himself would have killed 11 of them. The whole area was uninhabited, because the villages had not been rebuilt after the explosion of the Krakatau.

\section{Ujung Kulon as a nature reserve (1921-1937)}

Ujung Kulon was declared a "Natuurmonument" (Nature Reserve) on 16 November 1921 by Government Decree No. 60 (Staatsblad Nederlandsch Indie, no. 683). This automatically entailed the introduction of a total ban on killing or trapping any animal species and on the establishment of human settlements. At the time, however, there was no supervision to ensure that the laws were adhered to, and it was not forbidden to enter the forest.

The presence of the rhinoceros in the nature reserve was well-known at the time, but estimates of the size of the population were less reliable. Sody (1941: 54-55) quotes a letter dated 8 July 1932 received from Mr. Elbers, the administrator of an agricultural enterprise in Tjikandi Ilir near Serang. Elbers had regularly visited South Bantam and Ujung Kulon up to 1929 and had observed rhinos in the swampy area of the nature reserve between Tjikawoeng and Tjihaneuleum, as well as along the Tjigenter, Pamegeran, Tjitelang, Njioer and Moeara Oedjoeng Koelon (near the lighthouse). Although he estimated that there were about 100 rhinos at the time, he predicted their extermination because Chinese and Indonesian poachers had uncontrolled access in the absence of professional hunters. The same estimate of 100 animals was repeated by the (anonymous) AssistantResident of Lebak in a letter dated 11 May 1932 to Sody (1941: 55).

When Halewijn (1933) visited Ujung Kulon at the end of July 1931, he found several older rhino tracks, both near the lighthouse and elsewhere. In 1935, rhinos occurred in the swamps south of Java's third point, as well as to the east of the reserve in the vicinity of Pradana on the Peperbaai (Hoogerwerf \& van Steenis 1936: 48, 49). Franck (1935: 48-49) stated that the number of rhinos in Ujung Kulon could not be properly estimated for three reasons: visits to the reserve by Europeans were rare and generally too short; visitors did not explore those forests where rhino live during the day; and the forest personnel were not trained to assess the situation. When he compared the experiences of people who had been to Ujung Kulon between 1912 and 1935, he found that most had kept to the path which runs south from Meeuwenbaai. Rhino tracks had been found all over the reserve. He hoped that the current population would increase with proper management and protection, and suggested that at the time there were about 25-30 animals, possibly six males and 19-23 females.

There is regular evidence that rhinos and other animals were poached in Ujung Kulon during the 1930s. In February 1930, a Chinese man was found to have shot at least two rhinos within the area of Ujung Kulon (Sody 1941: 53, after Bataviaasch Nieuwsblad 25 February 1930). Although he was apprehended, he was released on a legal technicality (Bernard 1930; Leefmans 1931). In 1933 there were further reports of rhino poaching (Endert \& Dahler 1935: 15; Sody 1941: 55). On a visit in August 1934, Jan Scipio de Kanter, retired resident of Bantam, found clear signs of poaching activity in the area of the Tjikarang. When he had previously visited in October 1932, he had mentioned in his report that the police had solved nine cases of rhino poaching in the preceding 12 months (Hoogerwerf 1970: 63).

In 1936, rumours in the local media highlighted that a large number of rhinos had been illegally killed in Ujung Kulon in the last quarter of 1935. A reward of 250 guilders for information leading to an arrest offered by Johannes Cornelis Ligtvoet, Assistant-Resident of Pandeglang, had no result. Through information from a Chinese rhino poacher finishing 
his prison sentence and an intensive police investigation, many poachers were arrested, including the Wedana (district chief) of Tjibalioeng. The official enquiry by Ligtvoet (report dated July 1936) found that a poaching gang had succeeded in killing 15 rhino from October 1935 to April 1936 (Sody 1941: 56; Voogd \& Siccama 1939: 51; Hoogerwerf 1970: 64). One of the poachers was sentenced to 3 years in prison (Endert 1936: 18). The whole episode was brought before the "Volksraad" (National Assembly) in questions by the politician Jan Verboom (Voogd \& Siccama 1939: 51 with reference to the Appendix of the Handelingen van den Volksraad betreffende het zittingsjaar 1937-1938, p.8; Sody 1941: 56 following Algemeen Handelsblad, 4 December 1936). A subsequent nationwide investigation into the sale of rhino products as medicine found that the trade was flourishing all over Java. It was also decided to post five police officers at Karang-Randjang on the isthmus to the peninsula. An extensive intelligence system was organised covering much of western Java (Voogd \& Siccama 1939: 51-52).

Hoogerwerf visited Ujung Kulon in January 1936, paying attention to the security of the area. He suggested that there could never be adequate protection without the availability of a boat to aid in patrols (Hoogerwerf 1936). Requests for a motor launch to improve access and for additional guards were turned down by the government authorities in 1932 and 1936 (Hoogerwerf 1970: 16).

On 13 September 1937, one of the local newspapers in Java (Het Nieuws van den Dag voor Nederlandsch Indië) published a photograph of four skulls left in Ujung Kulon by poachers, but there is no report of the men ever being found (Sody 1941: 57, fig. 12).

\section{Ujung Kulon as a game sanctuary (1937-1949)}

Ujung Kulon was declared a "Wildreservaat" (Game Sanctuary) covering an area of 28.600 hectares by Decree No.17 of the Governor-General on 24 June 1937 (Staatsblad Nederlandsch Indië, no. 420). The eastern boundary was changed to effect a link with the forest reserve Gunung Hondjé. On 2 July 1938, the Director of Economic Affairs decreed that the park would be entirely closed to visitors, except with special permission obtainable from the Chief Forest Inspector (Besluit Directeur Economische Zaken, No. 10040/B.W./H.I., 2 Juli 1938). Sody (1941: 58) states that in reality only the East coast was closed as part of these new protection measures. However, a European guard was posted at Tamandjaja on the West coast to oversee a forest guard and boatsmen, while on the isthmus a new post was erected for two retired military men and a guard.

Hoogerwerf visited the reserve in an official capacity from the end of August to the beginning of October 1937. He found that the stock of game was satisfactory, including about 20-25 rhinos, but there was a great lack of pasture (Hoogerwerf 1938 1970: 18; Sody 1941: 58). On two visits in 1938, Hoogerwerf (1939) saw seven rhinos in Ujung Kulon, including at least one (possibly two) calf. A new surveillance system was devised, which was all that was deemed necessary at the time to protect the remaining rhinos. However, the structure of management was changed with almost immediate consequences.

In February 1939, a European poacher shot a female rhino and her calf in Ujung Kulon (Hoogerwerf 1970: 19, 64; also reported in Java-Bode of 3 May 1939 in Sody 1941:58 note 202). According to a speech by Verboom in February 1940, maybe as many as four rhinos had been poached in the previous year (Sody 1941: 58, note 202). In 1939, after the case of poaching had become public, some improvements to the management of the reserve were instituted, largely spearheaded by Maarten Hoek, the first forest official of Bantam. An improved patrol system around the perimeter of the whole reserve was instituted, old grazing grounds were restored, and regular transport to the island was maintained (Hoogerwerf 1970:19). Due to the additional vigilance, in October 1939, five Indonesians were caught while transporting parts of a freshly shot female rhino east of the reserve (Hoogerwerf 1970: 64).

Hoogerwerf made several excursions to Ujung Kulon in 1941. He encountered two rhinos on 14 February 1941, and another two on 28 May 1941 on the Tjigeunteur. Tracks were found on the shore opposite Meeuweneiland on 16 February 1941 (Hoogerwerf 1949). This visit was followed by a politically unstable period during the Japanese occupation of Java from March 1942 to 1945. Hoogerwerf accompanied a Japanese hunting party to Ujung Kulon from 6 to14 September 1942, partly to ensure that no rhinos would be killed, immediately followed by a short survey of the area with forest officials from 17 September to 11 October 1942 . He found fresh tracks and signs of feeding of rhinos at different locations, including some on the beach of both the northern and southern shore. Three rhinos in good condition were encountered and four times the animal was heard (Hoogerwerf 1946, 1948: 206).

He visited again from 30 December 1942 to 29 January 1943 to take steps for further surveillance of the reserve (Hoogerwerf 1970: 20). He found that the personnel were rarely to be found inside the reserve, and little work was done on maintenance of the pastures and the patrol trails. On 19 January Hoogerwerf's people were attacked by a couple of rhinos near the Tjitandahan river on the South coast. Personally, he only saw rhino tracks, but those included those of a calf accompanied by an adult as well as another group of animals (Hoogerwerf 1948: 210, 1949: 365, 1970: 21).

From July 1943 to April 1944, the forest guards submitted regular reports showing that rhinos were regularly encountered (Hoogerwerf 1949: 367). These included the following details of rhino sightings in 1943:

20 May - 6 June: 6 rhinos (5 males. 1 female) near north coast 21 June - 19 July: 9 rhinos (7.2) near north coast 19 July - 18 Aug: 10 rhinos (10.3) near south coast 19 Aug - 17 Sept: 8 rhinos (8.0) near north coast 17 Sept - 12 Oct: 11 rhinos (8.3) near south coast 17 Oct - 6 Nov: 15 rhinos (13.2) near south coast

Most rhinos were found solitary or in pairs, but once an unusual group of three specimens was recorded. From February to March 1944 the guards saw four rhinos (Hoogerwerf 1946: 207). On 29 October 1943, forest guards found the remains of a freshly poached rhino inside the reserve lying in a mudhole not far from the northern coast, along the Legon Penju. The owner of the gun used in the incident was sentenced to 9 years imprisonment for illegal possession of a firearm, but the poachers could not be apprehended (Hoogerwerf 1970: 21, 64).

The period after the end of the Japanese occupation was chaotic and any direct management of the reserve was impossible. From 1946 to 1950, at least five rhinos were poached (Hoogerwerf 1970:21, 64). Fortunately, during a visit to the reserve in November-December 1950, Hoogerwerf found a good number of rhino tracks. He was certain that he saw tracks of ten different animals, albeit no calves, but that of course had always been a rare occurrence. Although he did not estimate total numbers, he was happy to witness that the 
rhino population had not deteriorated too much during the period of war (Hoogerwerf 1950: 55-58, 1970: 21).

\section{Discussion}

Fernando et al. (2006: 445), as part of the discussion on genetic variability, suggest that the "catastrophic explosion of Krakatoa in 1883, and its aftermath, in addition to annihilating the human settlements in Ujung Kulon, would likely have exterminated the Javan rhinos then inhabiting the peninsula. The present day Javan rhino population probably originated from subsequent re-colonization." However, this welldocumented and carefully written paper does not justify this statement, nor provide any reference to another source for this conclusion. As far as we are aware, the idea of the local extermination of rhinoceros in Ujung Kulon and subsequent re-colonization has not before been elucidated, hence the idea would benefit from further discussion. The historical data on the early human settlements in Ujung Kulon are patchy, but most sources agree that, outside the immediate surroundings of the lighthouse, there has only been one sizeable village on the peninsula during most of the $19^{\text {th }}$ century. This village was abandoned or evacuated in 1906, possibly under pressure from the government due to the prevalence of diseases and a rise in the number of tigers. There is no evidence that the eruption of the Krakatoa had a lasting influence on the population of the village, even though it obviously created great disturbance when it occurred.

The impact of the volcanic eruption on the wildlife in Ujung Kulon is even more uncertain. There could have been casualties, or possibly large mammals like the rhino were able to withstand the waves. There may have been changes in the flora caused by the salt water, but if this had any effect on the browsers and grazers is unknown. The reports on the rhinoceros in the region have always been sketchy. The animals were regularly reported in Ujung Kulon, both before the eruption of 1883 and afterwards. In the literature, we are unable to find any statement that the rhino population particularly suffered during the period. Rhinos were sighted in Ujung Kulon in 1892, 1906 and 1908, and of course regularly afterwards. Before the catastrophe, there were no definite estimates of rhino numbers. After it, there were suggestions that the rhinos numbered anywhere between 20 and 100 (Hoogerwerf 1970: 70). None of these figures was based on a long-term or intensive survey of the entire area, hence possibly the wide range in the estimates. There is, however, in our view no evidence that all rhinos in Ujung Kulon disappeared during the decade after the eruption of the Krakatoa in 1883.

\section{References}

Adams, A. (1861). Beetling at the Cape and in Java. Zoologist 19: 7325-7329.

Appelman, F.J. \& P.F. Franck (1934). Rhinoceros sondaicus in West-Java. Tropische Natuur 23: 73-76, figs. 1-2.

Becking, J.H. (1989). Henri Jacob Victor Sody (1892-1959): his life and work, a biographical and bibliographical study. E.J. Brill, Leiden, viii+272pp.

Bernard, C. (1930). Verkorte notulen der jaarvergadering van de Ned. Ind. Ver. tot Natuurbescherming op 23 maart 1930 gehouden te Buitenzorg. Tropische Natuur 19(5/6): 107-108.

Bremer, H. (1908). Indien in Moll, Java: Reiseerinnerungen und Betrachtungen. Union, Stuttgart, Berlin, Leipzig, vi+200pp.

Eekhout, R.A. (1911). Prinseneiland en schiereiland Djoengkoelan. Indische Mercuur 34(4): 66-67.

Endert, F.H. (1936). Verkorte notulen der vergaderingen van het dagelijks bestuur. Verslag van de Nederlandsch Indische Vereeniging tot Natuurbescherming 10: 10-20.

Endert, F.H. \& E. Dahler (1935). Notulen der algemeene vergadering op 17 Maart 1934 te Buitenzorg. Verslag van de Nederlandsch Indische Vereeniging tot Natuurbescherming 1933-1934: 14-16.

Ernst, A. (1908). The New Flora of the Volcanic Island of Krakatau, translated by A.C. Seward. C.U.P., Cambridge, vi+74pp.

Fernando, P., G. Polet, N. Foed, L.S. Ng, J. Pastorini \& D.J. Melnick (2006). Genetic diversity, phylogeny and conservation of the Javan Rhinoceros (Rhinoceros sondaicus). Conservation Genetics 7: 439-448, figs. 1-3, tables 1-2.

Franck, P.F. (1935). Waarnemingen over neushoorns en bantengs in het natuurmonument "Oedjon Koelon". Verslag van de Nederlandsch Indische Vereeniging tot Natuurbescherming 19331934: 40-55, figs. 1-2.

Groves, C.P. (1967). On the rhinoceroses of South-East Asia. Säugetierkundliche Mitteilungen 15(3): 221-237, figs. 1-4, tables 1-5.

Groves, C.P. \& C. Guérin (1980). Le Rhinoceros sondaicus annamiticus d'Indochine: distinction taxinomique et anatomique; relations phyletiques. Geobios 13(2): 199-208, figs. 1-4, tables 12.

Halewijn, E. (1933). De fauna van Prinsen-Eiland, Meeuwen-Eiland en van het natuurmonument Oedjoengkoelon. Verslag van de Nederlandsch Indische Vereeniging tot Natuurbescherming 1932: 31-35

Hall, B. (1826). Voyage to Loo-Choo, and other places in the Eastern seas, in the year 1816: including an account of Captain Maxwell's attack on the batteries at Canton; and notes of an interview with Buonaparte at St. Helena, in August 1817. Archibald Constable \& Co., Edinburgh and Hurst, Robinson, \& Co., London, 81pp.

Hawkesworth, J. (1783). An account of the voyages undertaken by the order of His present Majesty for making discoveries in the Southern Hemisphere, and successively performed by Commodore Byron, Captain Wallis, Captain Carteret, and Captain Cook, in the Dolphin, the Swallow, and the Endeavour: drawn up from the journals which were kept by the several commanders, and from the papers of Joseph Banks, esq., vol. 3. W. Strahan and T. Cadell, London, 395pp.

Hoogerwerf, A. (1936). Rapport over een bezoek aan het natuurmonument Oedjoengkoelon. Verslag van de Nederlandsch Indische Vereeniging tot Natuurbescherming 10: 114-116.

Hoogerwerf, A. (1938). Among rhino and Javanese wild ox (banteng) in the Oedjoeng Koelon Game Reserve. Nature Protection in the Netherlands Indies 1938: 1-8.

Hoogerwerf, A. (1939). Wildreservaat Oedjong Koelon: de wildstand in Java's schoonste natuurpark. Verslag van de Nederlandsch Indische Vereeniging tot Natuurbescherming 11: 172-213, figs. 34-52.

Hoogerwerf, A. (1946). Jacht en natuurbescherming op Java gedurende de Japansche bezetting. Natuurwetenschappelijk Tijdschrift voor Nederlandsch Indie 102(9): 205-208.

Hoogerwerf, A. (1948). Enkele waarnemingen in het natuurmonument Oedjoengkoelon in de bezettingstijd. Tectona 38(4): 205-214.

Hoogerwerf, A. (1949). Ontmoetingen met Javaanse neushoorns in het natuurpark Oedjong-Koelon (West Java), pp. 359-370, figs. 1-9. In: Besemer, A.F.H. (ed.). In het voetspoor van Thijsse, een reeks bijdragen over veldbiologie, natuurbescherming en landschap. H. Veenman \& Zonen, Wageningen, 413pp.

Hoogerwerf, A. (1950). Verslag van een reis naar het wildreservaat Udjung-Kulon (van 21 november - 9 december 1950): 30ste dienstrapport. Mededelingen van de Nederlandse Commissie voor Internationale Natuurbescherming 14: 7-93, pls. 1-5, map 1.

Hoogerwerf, A. (1970). Udjung Kulon, the land of the last Javan rhinoceros. With local and general data on the most important faunal species and their preservation in Indonesia. E.J.Brill, Leiden, xiii+512pp.

Hoogerwerf, A. \& C.G.G.J. van Steenis (1936). Berichtgeving over natuurbescherming in 1935. Verslag van de Nederlandsch Indische Vereeniging tot Natuurbescherming 10: 24-104.

Kal, H.T. (1910). Het schiereiland Djoengkoelon. Tijdschrift Binnenlands Bestuur 39: 136-140. 
Kerkhoven, A.R.W. (1926). Rhinoceros-jacht op Java. Nederlandsche Jager 32(21): 326-329, fig. 1.

Koorders, S.H. (1916). Beknopt overzicht van eenige Nederl. Indische natuurmonumenten, die tot het Landsdomein behoren en waarvoor Staatsbescherming noodig geacht wordt. Verslag van de Nederlandsch Indische Vereeniging tot Natuurbescherming 1: 164.

Leefmans, S. (1931). Jaarverslag over 1930. Verslag van de Nederlandsch Indische Vereeniging tot Natuurbescherming 19291931: 27-31.

Maier, P.J. (1853). Onderzoek naar steenkolen in de nabijheid der Meeuwenbaai (zuidwesthoek van Java). Natuurkunding Tijdschrift voor Nederlandsch Indie 5: 353-363.

Osbeck, P. (1765). Reise nach Ostindien und China. Aus dem Schwedischen übersetzt von J.G. Georgi. Johann Christian Koppe, Rostock, xiv+552pp.

Schenkel, R. (1971). Mission Nashorn: auf der Fahrte des seltensten Saugetiers der Welt. Hallwag, Bern and Stuttgart, 219pp.

Schenkel, R. \& L. Schenkel (1969). The Javan rhinoceros $(R h$. sondaicus Desm.) in Udjung Kulon Nature Reserve: its ecology and behaviour: Field study 1967 and 1968. Acta Tropica 26(2): 97-135, figs. 1-9, tables 1-9.

Smit, W.M. (1854). Vervolg van het onderzoek naar steenkolen, in de nabijheid der Meeuwenbaai (zuidwesthoek van Java). Natuurkunding Tijdschrift voor Nederlandsch Indie 6: 509-515.

Sody, H.J.V. (1941). De Javaansche neushoorn, Rhinoceros sondaicus, historisch en biologisch. Archipel Drukkerij en ' $T$ Boekhuis, Buitenzorg, vii+156pp.

Sody, H.J.V. (1959). Das Javanische Nashorn, Rhinoceros sondaicus, historisch und biologisch. Zeitschrift für Säugetierkunde 24 (3/4): 109-240, figs. 1-13.

Sturler, V.de (1915). Geschenk van een Rhinoceros sundaicus. Jaarboek Departement Landbouw Nijverheid en Handel, Batavia 1914: 63-64.

Verbeek, R.D.M. (1885). Krakatau. Imprimerie de l'État, Batavia, $\mathrm{Xl}+557 \mathrm{pp}$.

Veth, P.J. (1875). Java: geographisch, ethnologisch, historisch, vol. 1. Erven F. Bohn, Haarlem, viii+672pp.

Voogd, C.N.A. de \& G.F.H.W. Rengers Hora Siccama (1939). Berichtgeving omtrent natuurbescherming over 1936-1938: onderwerpen van lokalen aard residentiegwijs gerangschikt. Verslag van de Nederlandsch Indische Vereeniging tot Natuurbescherming 11: 49-154.

Weede, H.M. van (1908). Indische reisherinneringen. H.D. Tjeenk Willink, Haarlem, 526pp.

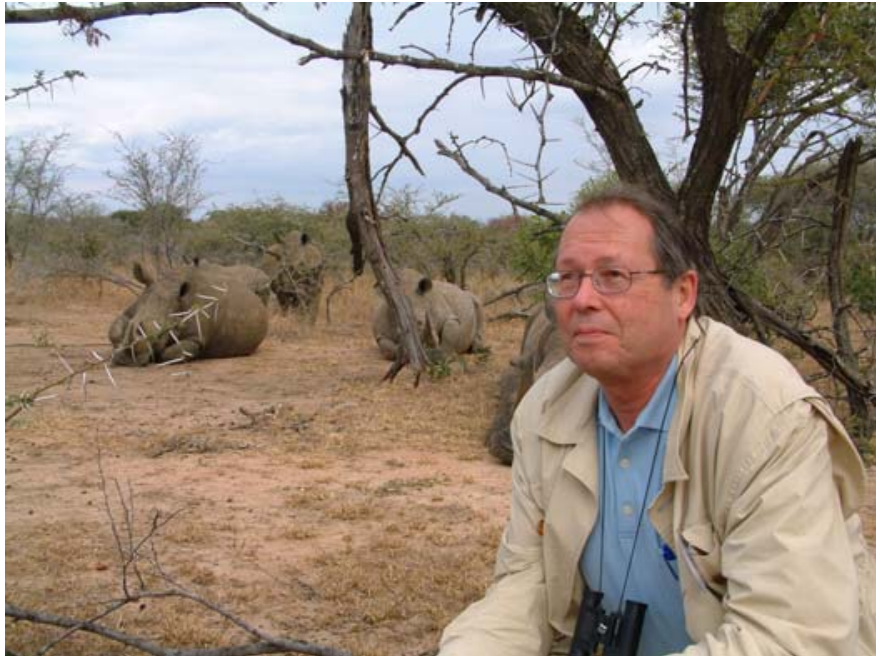

Nico van Strien observing white rhino in 2006

Nico van Strien (1 April 1946 - 7 February 2008) was a well-known biologist interested in the birds and mammals of Africa and SouthEast Asia. He will certainly be remembered for his indefatigable efforts to save the rhinos in Indonesia. From 1975 to 1980 , Nico made several excursions into the remotest parts of the Gunung Leuser National Park on Sumatra with the intention to study the ecology of the Sumatran rhinoceros. These are elusive animals, and the only way to get results was to design a technique to monitor their footprints and other signs. He was able to present his data as a dissertation in 1985, which is one of the few major studies on the subject. Nico liked field-work, but was no less at home in libraries and museums, where he traced previous relevant publications. He knew that sound academic research as well as effective conservation need to be based on the experiences and observations of all generations and all backgrounds. In his later years, Nico was active as the Asia Rhino Program Coordinator of the International Rhino Foundation and as the Co-Chair of the Asian Rhino Specialist Group. His expertise and leadership were remarkable. On 10 January 2008, his health weakened by incurable prostrate cancer, his friends and colleagues received an email message from Nico to share his decision "that whatever energy and time remains should be devoted to my family and friends. And that I should cease all my official and unofficial functions and duties. I want to thank you for all the things that we've been able to do together for the benefit of conservation in South East Asia and in particular for the Asian rhinos. Together we've been able to do many useful programs and projects and many good friendships and professional relationships were formed." Nico must have struggled to write these words, just as many of the recipients much have silently wept. We lost a fighter for nature study and conservation at the height of his ability. He spent his last days in Holland with his wife Tineke and his sons Maarten and Willem. Let us continue the fight to save wildlife in Asia and Africa with similar selfless dedication. -- Kees Rookmaaker. 